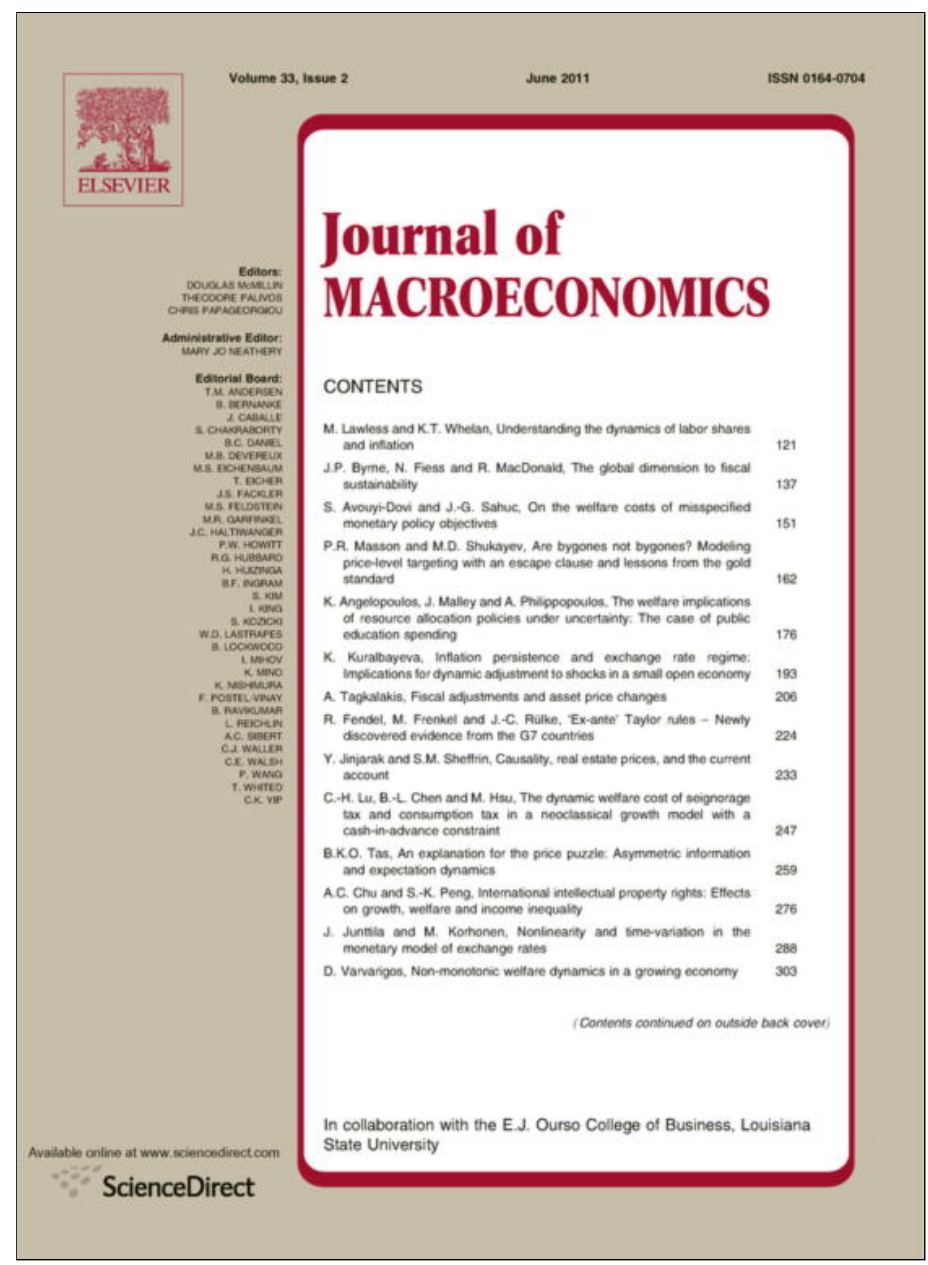

This article appeared in a journal published by Elsevier. The attached copy is furnished to the author for internal non-commercial research and education use, including for instruction at the authors institution and sharing with colleagues.

Other uses, including reproduction and distribution, or selling or licensing copies, or posting to personal, institutional or third party websites are prohibited.

In most cases authors are permitted to post their version of the article (e.g. in Word or Tex form) to their personal website or institutional repository. Authors requiring further information regarding Elsevier's archiving and manuscript policies are encouraged to visit:

http://www.elsevier.com/copyright 


\title{
Causality, real estate prices, and the current account ${ }^{\text {th }}$
}

\author{
Yothin Jinjarak $^{\mathrm{a}, *}$, Steven M. Sheffrin ${ }^{\mathrm{b}}$ \\ ${ }^{a}$ Department of Financial and Management Studies, 534 College Buildings, SOAS, University of London, WC1H 0XG, United Kingdom \\ ${ }^{\mathrm{b}}$ Murphy Institute and Department of Economics, 108 Tilton Hall, Tulane University, New Orleans, LA 70115, United States
}

\section{A R T I C L E I N F O}

\section{Article history:}

Received 26 June 2010

Accepted 1 November 2010

Available online 12 November 2010

\section{JEL classification: \\ C80 \\ F21 \\ F32 \\ R21 \\ R31 \\ Keywords: \\ Causality \\ Current account \\ Graph-theoretic \\ Real estate \\ VAR}

\begin{abstract}
A B S T R A C T
This paper explores the causal relations between real estate prices and the current account using recently developed econometric methods for recursive systems. Using a variety of high-quality real estate indices, we find little evidence that current account deficits (capital account surpluses) directly drove real estate prices in the United States, Spain, and Ireland. There is some evidence for this linkage in England; however it is transitory and not persistent. There is also strong evidence that current account surpluses have direct impacts on mortgage rates in the United States, providing an indirect channel for stimulating the real estate market mediated through the financial markets.
\end{abstract}

(c) 2010 Elsevier Inc. All rights reserved.

\section{Introduction}

"There are some encouraging signs coming from the feeble British housing market, where prices are down on average 15 percent from their 2007 peak. ... New buyer inquiries also rose - many of them from apparently wealthy non-Britons looking to snap bargains. ... In a further indication of an incipient recovery, foreign lenders like the Bank of China also have started to expand their mortgage offerings in Britain... The increase in housing prices, helped by purchases in prime areas of London like Chelsea and Knightsbridge, is mainly the result of a shortage of properties. ... A relatively high proportion of people in Britain own houses, and, unlike Americans, we mainly have variable rate mortgages, which means that income flows vary and there's a more direct link to consumption levels,'..."

International Herald Tribune, August 6, 2009.

The world financial crisis in 2007 and 2008 was characterized by capital flows, housing meltdown, credit freeze, stock market crash and economic slump. As research by Aizenman and Jinjarak (2009) reveals, this linkage is not new, particularly the close ties between movements in the real estate markets and capital flows. But the interpretation of the linkages between real estate prices and capital flows is subject to considerable debate, even in the most recent crisis.

\footnotetext{
We have benefited from the comments of seminar participants at the IMF European Department and the Federal Reserve Bank of Dallas.

* Corresponding author.

E-mail addresses: yothin.jinjarak@soas.ac.uk (Y. Jinjarak), smsheffrin@tulane.edu (S.M. Sheffrin).
} 
One school of thought suggests that capital inflows to the United States were the ultimate driver of the real estate bubble and ultimate financial crisis. Federal Chairman Ben Bernanke provided the intellectual roots for this idea several years ago when he talked about a "global savings glut" stemming primarily from Asia. ${ }^{1}$ The savings glut, of course, was the mirror image of the US current account deficits, but Bernanke's choice of term suggested causality from the high savings countries to the US. It is a short step from there to recognize that this will appreciate assets with relatively fixed supplies, including real estate. Of course, the Asian countries had little to do with the intricacies of failed securitization schemes, but under Bernanke's view, their savings behavior was the ultimate cause of the recent crisis.

Bernanke's primacy of capital flows ties in closely to previous work on financial crises, particularly in developing countries with fixed exchange rates. Although they differed in precise form, both Mexico and Asian countries during the 1997 crisis initially experienced capital inflows, appreciating real estate, and sharp increases in the real exchange rate. Ultimately, these patterns were not sustainable and these economies experienced financial meltdowns and severe recessions. Reinhart and Rogoff (2008) explore the pattern of recessions generated by banking and financial crises across countries and suggest similarities in economic outcomes following the crisis across a wide array of countries. By focusing on a recessions caused by banking and financial crises, they implicitly imposed a causal framework related to Bernanke's, although perhaps not directly tied to the current account.

An alternative view, however, would suggest that the causality between real estate price increases and the current account would run the other way. Optimism or animal spirits could drive individuals to purchase assets and appreciation of assets would spur further purchases. As perceived wealth increases from asset appreciation-perhaps fueled by sophisticated financial intermediation-households would decrease their savings, and business might be led to make increased investments. With increased absorption, the current account would deteriorate and capital flows would provide the financing for the additional consumption and investment. Here the causality runs from speculation and real estate prices increases to the current account. With a different ultimate causal impulse for the recession, the effects on the economy over time may differ from recessions whose origin was primarily from capital inflows. At the macro level, increases in equity prices are often closely related to short-run appreciation in real estate prices and subsequently, income and economic growth. Since the dynamics in real estate markets are slower than that in the equity markets [Case and Shiller (2005), Glaeser and Gyourko (2007)], causality may run from equity price appreciation to current real estate valuation.

Another possibility is that capital account surpluses could lead to lower domestic interest rates, which in turn influence both equity prices and housing prices. In this case, the links between the current account and real estate prices would be indirect and mediated through financial market channels.

Micro-level studies have established links between housing prices, financial market conditions, and consumption behavior, but have not resolved the causality issue. For the US, much of the empirical evidence is based on the PSID household level data. Yamashita (2007) finds that the use of home equity for consumption in response to house price appreciation is negatively associated with homeowner's ration of wealth to income. Engelhardt (1996) finds a low marginal propensity to consume out of real housing capital gains. In England, micro data show the effect of house prices on consumption increases with age and borrowing constraint, driven by national rather than regional house prices, suggesting that house prices are correlated with aggregate financial market conditions (Campbell and Cocco, 2007).

How can the causal relations between real estate movements and the current account be untangled in dynamic economic systems? Economists have taken a number of different approaches to determining causal structure in multivariate time series settings. The first approach is just to assume one-either through a priori restrictions in the Cowles Foundation approach applied to structural VARs or through the choice of a specific recursive ordering or Cholesky factorization chosen by the investigator. Once a causal structure has been chosen, it is possible to derive impulse response function and variance decompositions, but ultimately these results are all based on the a priori assumptions that went into the choice of causal model.

Other approaches rely on some external information. Hoover and Sheffrin (1992) show how structural breaks coupled with some a priori information can be used in some circumstances to identify causal structures. This approach depends on determining structural breaks in time series (additional information) but is applicable only in bivariate settings. Romer and Romer (2010) attempt to read the historical record (another source of a priori information) to try to adduce "policy shocks". But their work is at best limited to analyzing policy interventions and not useful for general causal inference.

What about approaches that rely simply on the time series themselves? Granger causality or, more precisely, Granger "incremental predictability" is used frequently by economists. But it is well known that in intertemporal models, Granger causality can give the incorrect answer to casual ordering. Since both consumption and investment behavior are, in part, forward looking, this method is not appropriate for our task.

There is one additional method for helping to determine causal structure using solely the underlying data that is increasingly being used in the econometric literature. This is the approach based on the insights of graph theory due to Pearl (2009) and Spirtes et al. (2000) and used in economic applications by Sheffrin and Triest (1995), Granger and Swanson (1997), Demiralp and Hoover (2003), Perez and Siegler (2006), and Hoover et al. (2009). This approach restricts the class of models to recursive models, just as in the original VAR literature. It uses some results from graph theory to reduce the set of possible causal structures by examining correlations and conditional correlations in the data-in our model, the residuals from an

\footnotetext{
1 See Bosworth and Flaaen (2009) for useful background information on both capital flows and financial intermediation and comments on his paper by Steven Sheffrin in that volume.
} 
unrestricted VAR. While the restriction to recursive settings does limit the class of models that can be examined, this method can handle multiple time series in a straightforward manner.

Since the theory has been presented in more detail elsewhere, we just give a very brief summary in the next section so the reader will be familiar with the key terms. We then begin our econometric exploration of the extensive data we have compiled on real estate prices and the current account across and within countries and time periods. We estimate a series of VARs and then use the residuals as the appropriate output for our causal investigations. The results of this investigation will lead us to conclusions on the causal relations between real estate prices and the current account.

\section{Graph theory and causal structure}

We draw on the discussions in Sheffrin and Triest (1995) and some unpublished lectures given by Kevin Hoover to provide a brief overview of our method. ${ }^{2}$ In order to make inferences about the nature of causal structure from the data, there needs to be connections between the properties of causal models and probability structures in the data. The approach that we use in our work links the structure of causal models to conditional independence relations among the variables in the model. The essential idea is that tests for independence and conditional independence among the variables in a model can be informative about the structure of models.

Any linear, recursive simultaneous model can be represented by a directed, acyclical graph denoted $\langle V, E\rangle$ where $V$ is the set of vertices of the graph and $E$ is the set of directed edges. The vertices represent variables and the directed edges represent causal linkages. Directed edges or arrows represent causal direction. All variables that have a directed edge into them also have associated with them an independent, normal error term, although these are typically not shown in the graphs. A graph is acyclical if no causal chains come back to the same variable - this rules out simultaneous structures.

To develop the theory, we need some terminology from graph theory. Two variables, $p$ and $q$, are adjacent if either $\mathrm{p}$ is a direct cause of $q$ or $q$ is a direct cause of $p$. Finally, if $p$ and $q$ both cause $r$ but $p$ and $q$ are not adjacent, then $r$ is an unshielded collider. This is an important concept and in can be represented simply as follows: $p \rightarrow r \leftarrow q$.

The key result in graph theory is that, under some technical conditions, two graphs entail the same conditional independence relations if and only if (a) they have the same adjancies and (b) the same unshielded colliders. These results are the key to the empirical analysis. Algorithms are developed to test for both adjacencies and unshielded colliders [ $p \rightarrow r \leftarrow q]$. To test the latter, a key principle is that, for an unshielded collider, $p$ and $q$ are independent, but dependent, conditional on $r$. If the data is sufficiently informative, then it may be possible to rule out possible causal orderings.

In practice, to identify causal orderings from conditional correlations, we use the programs and algorithms available in the program TETRAD which was developed by Spirites, Glymour, and Scheines at Carnegie Mellon. ${ }^{3}$ In econometric VAR applications, we first estimate unrestricted VARs. Then, following the practice originated by Granger and Swanson (1997), we use the residuals from the regressions to determine what causal structures are present in the data. Once we have identified a causal structure, then we can give a structural interpretation to the VAR through an appropriate transformation.

\section{Our data and causal orders}

\subsection{Data}

The variables of interests are current account/GDP, real estate prices, interest rates, equity prices, and output growth. We collect quarterly data at the longest span possible for each covariate (the Appendix A provides the source and sample period). The current account balances and GDP are obtained from the Eurostat. To construct equity market appreciation, we use CPI inflation to convert the national market index to real terms: NYSE Composite for the US, FTSE All share for England, ISEQ for Ireland, and Madrid SE General for Spain. For interest rates, we use mortgage rates and prime lending rates. While the majority of housing loans in for the United States are under fixed rates, we use both Freddie Mac 30-year fixed-rate mortgage rate and 1-year Treasury-indexed adjustable-rate mortgage (ARM) rate. As a higher proportion of homeowners in England have variable-rate mortgages, we use standard variable-rate mortgage rates from the Banks \& Buildings Society (Bank of England database). Subject to data availability, we use the house purchase loan average interest rate (all credit institutions, compiled by the Central Bank of Ireland) for Ireland, and the average interest rate of loans (5-10 years) to households for house purchase (reported by the IMF) for Spain.

To account for heterogeneity in the real estate markets, we measure the appreciation (in real terms, deflated by CPI) of real estate prices at the national level, by regions and cities, as well as across the real estate types. For the United States, national and regional (west, south, east, and mid-west) level data are from the National Council of Real Estate Investment Fiduciaries (NCREIF); data at city level (10 cities) are available from Case-Shiller S\&P. For England, house price data at the national and regional (South East, London, West Midlands, East Midlands, Yorkshire and Humberside, East, North East) come from Nationwide Building Society and Department for Communities and Local Government (DCLG), respectively; data by real estate types (office, retail, industrial, total) are taken from Investment Property Databank (IPD). For Ireland, we use

\footnotetext{
2 Hoover's lectures are accessible through the Courses link on his web page, http://www.econ.duke.edu/ kdh9/.

3 It is available at http://www.phil.cmu.edu/projects/tetrad/.
} 

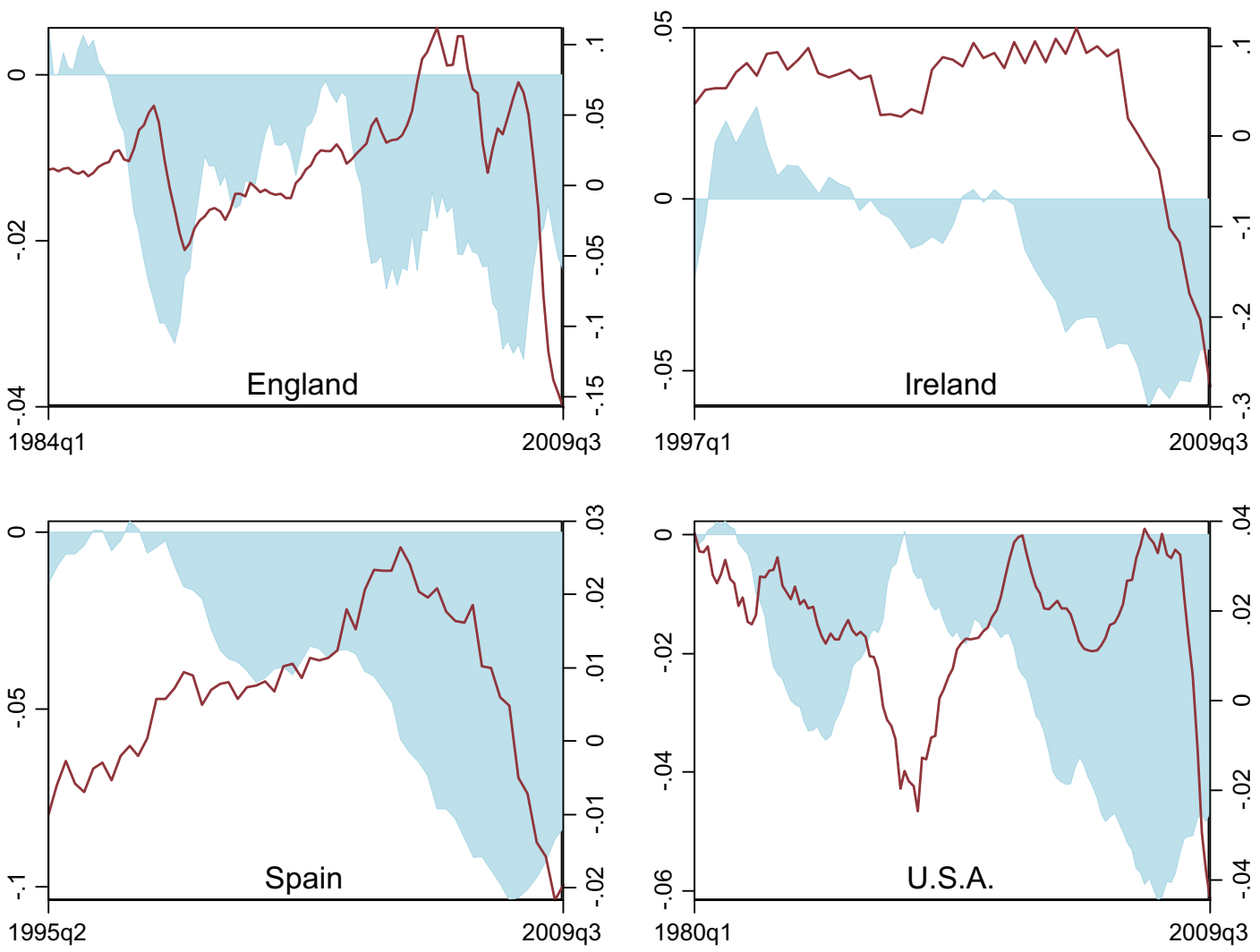

Fig. 1. Current account and real estate prices. This figure depicts four-quarter moving averages of current account balances/GDP (left-scale area) and real appreciation of real estate prices (right-scale line; real estate appreciation deflated by CPI inflation).

national house price index from Department of the Environment and Local Government, and data by real estate types from IPD. For Spain, the house price index data is taken from Ministerio de Vivienda.

We find that more than half of these quarterly series are nonstationary. ${ }^{4}$ As is well known, due to the power of unit root tests and limited sample size, the available tests tend not to reject variables supposed to be stationary in the long run, including the current account/GDP. Unlike most applications of the graphical analysis which deal with cross-section data, we are concerned by spurious correlations as a result of nonstationarity in our time series data. Hence, the following analysis will be conducted on a sample with stationary series, where we selectively difference the nonstationary variables based on the results of the unit root tests. We have also conducted the estimation with all the variables entered into the estimation in levels (no transformation); these estimates are reported in the working paper version of this paper and available upon request, as we give larger interpretative weight on results from the sample of stationary series.

\subsection{Contemporaneous causal order}

By and large, it is difficult to gauge causal correlation simply from the co-movements between current account and real estate prices as shown in the plots of current account balance to GDP and real estate appreciation in Fig. 1. Over the last 15 years, real estate prices in the United States appreciated in real term by $108 \%$, England by $161 \%$, Ireland by $232 \%$, and Spain by $40 \%$. During the same 15-year period, current account deficits to GDP have increased on a quarterly basis by $.09 \%$ in the US, .04\% in England, .15\% in Ireland, and .01\% in Spain. While this may lead to the conclusion that capital account surpluses cause real estate appreciation, the relationship is not that simple as the appreciation can also be attributed to different economic environments that vary across time and countries. Further, both current account and real estate prices could be driven by other common causes, including equity markets, real interest rates, and output growth.

To disentangle the causation, we follow Hoover et al. (2009) by first estimating a vector autoregression (VAR) with key variables: current account to GDP (CAGDP), real estate appreciation (RECPI), real interest rate (INCPI), equity market appreciation (EQCPI), and output growth (GDPGR). Starting with a structural VAR (SVAR):

$$
A_{0} Y_{t}=A(L) Y_{t-1}+E_{t}
$$

where $Y_{t}$ is an $n \times 1$ vector of contemporaneous variables, $A_{0}$ is $n \times n$ matrix; $A(L)$ is a polynomial in the lag operator, $L$; $E_{t}$ is an $n \times 1$ vector of error terms. The SVAR yields the unrestricted VAR or reduced form that is observable in the data.

\footnotetext{
${ }^{4}$ Based on the Phillips-Perron test under the null of unit root. The Appendix A provides p-values of the tests.
} 


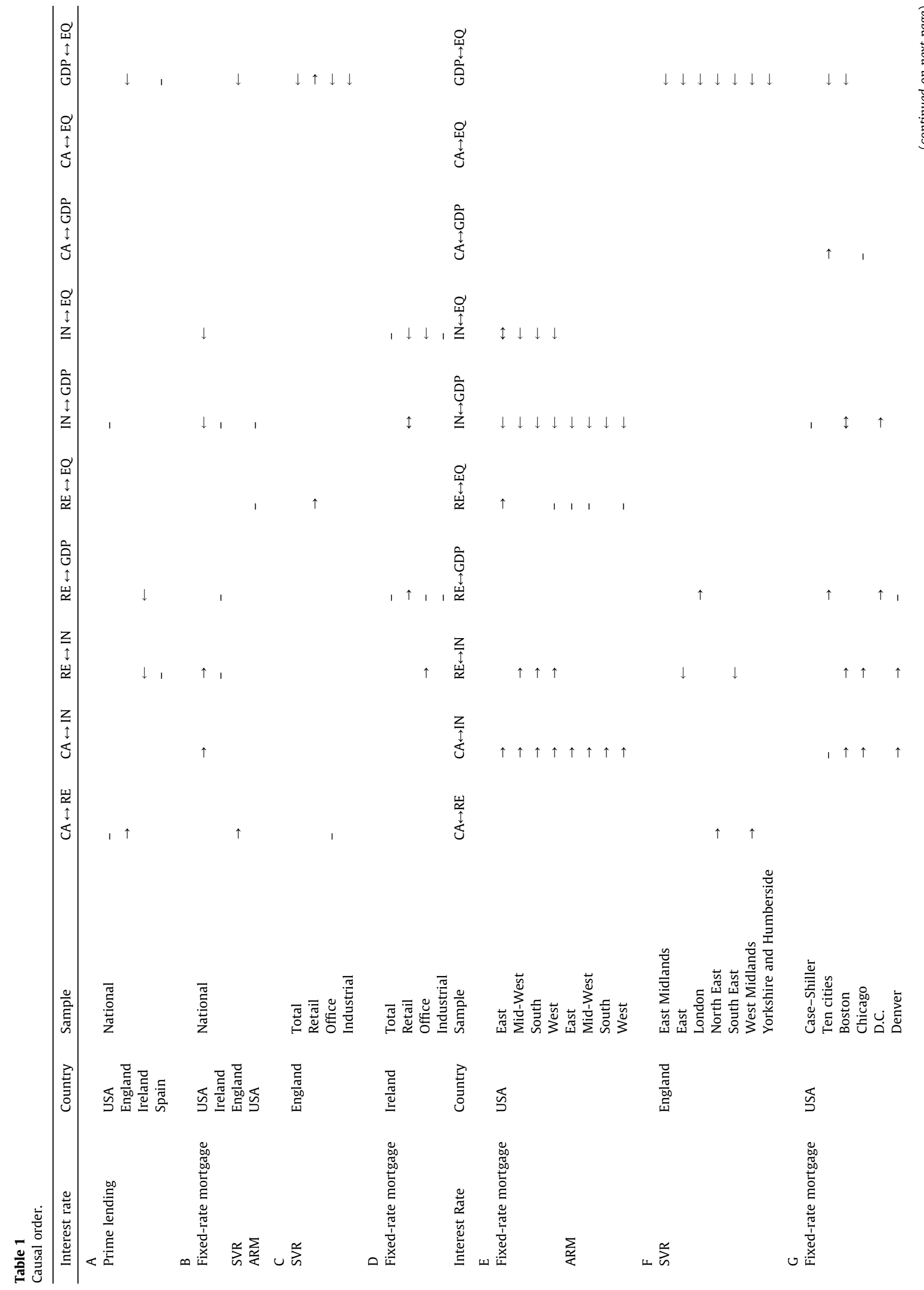




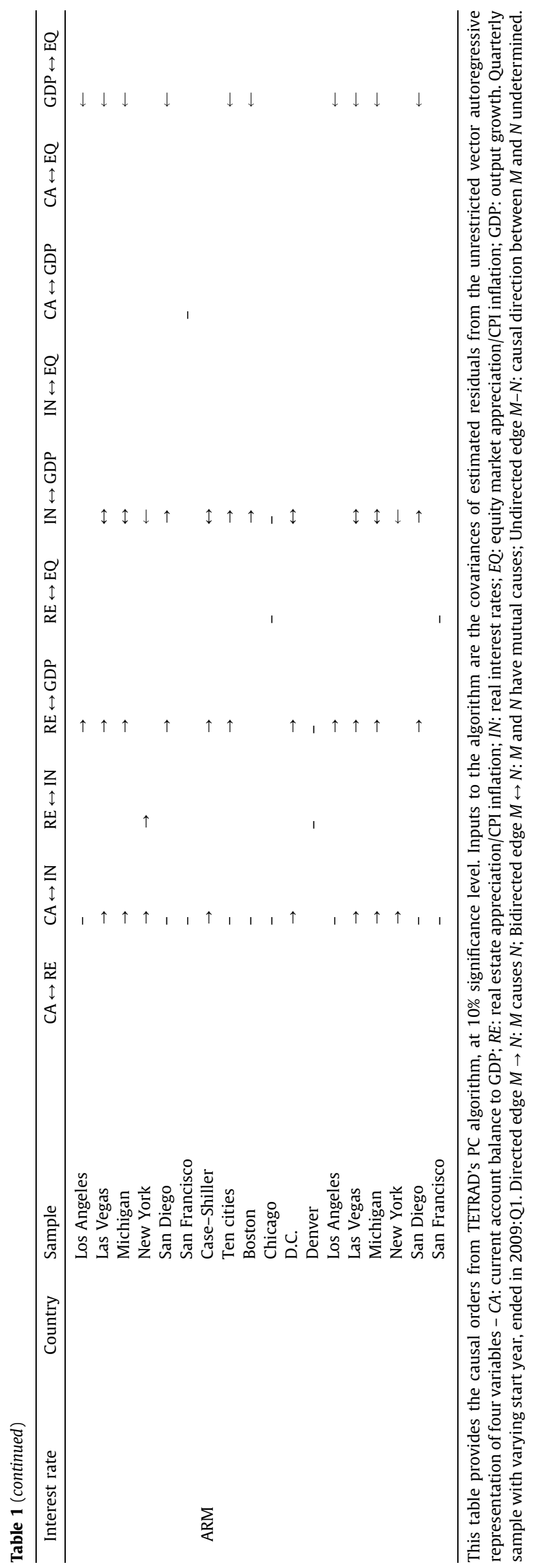



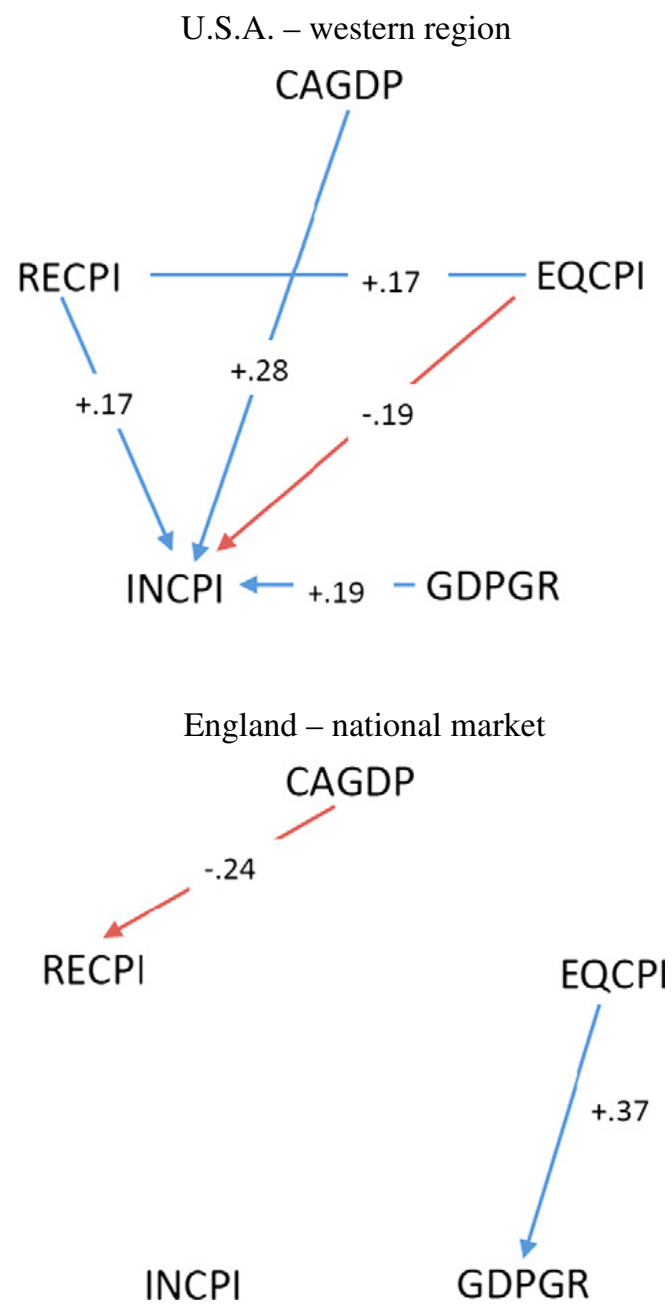

Fig. 2. Selected causal orders. This figure depicts the causal orders from TETRAD`s PC algorithm, at 10 percent significance level. Inputs to the algorithm are the covariances of estimated residuals (correlation coefficients reported in the figure) from the unrestricted vector autoregressive representation of four variables - CAGDP: current account balance to GDP; RECPI: real estate appreciation/CPI inflation; INCPI: real interest rates (fixed-rate mortgage for USA western region; variable rate for England - national market); EQCPI: equity market appreciation/CPI inflation; GDPGR: output growth. Quarterly sample with varying start year, ended in 2009:Q1.

$$
\begin{aligned}
Y_{t} & =A_{0}^{-1} A(L) Y_{t-1}+A_{0}^{-1} E_{t} \\
& =B(L) Y_{t-1}+U_{t}
\end{aligned}
$$

We perform a number of lag-order selection tests. The Schwarz's Bayesian information criterion (SBIC) and the Hannan and Quinn Information Criterion (HQIC) statistics tend to suggest at most two lags, while the Final Prediction Error (FPE) statistics suggest four lags. Following the approach of Demiralp et al. (2009), we keep the variable-specific dynamics simple and not too restrictive, and set the lag length to four. Using four lags, we input the covariance matrix of the estimated $U_{t}$ to TETRAD's PC algorithm. Following the literature, we use Directed edge $M \rightarrow N$ : $M$ causes $N$; Bidirected edge $M \leftrightarrow N: M$ and $N$ have mutual causes; Undirected edge $M-N$ : causal direction between $M$ and $N$ undetermined. Table 1 reports the causal orders (10\% critical value). For the real estate appreciation at the national level and other covariates, Panels $1 \mathrm{~A}$ and $1 \mathrm{~B}$ provide their causal orders where we use prime lending rates and mortgage interest rates, respectively. For USA, we report the estimation both for fixedrate and flexible-rate mortgage rates. Panels 1C and 1D provide the causal order by real estate sectors for England and Ireland, respectively. Regional-level causalities for USA. and England are reported in Panels 1E and 1F. Lastly, Panel 1G shows the causal links for USA at city level. As shown, the contemporaneous structure selected by the algorithm varies greatly across countries and choices of real estate indices, and whether we use fixed-rate or adjustable-rate mortgage rates in the computation.

However, a few key patterns do appear to emerge from the table. First, only for England is there any identified causal relationship from the current account to real estate prices (Panel $1 \mathrm{~B}$ for the national market and Panel $1 \mathrm{~F}$ for the Northeast and West Midlands regions). For Ireland, we find linkages between real interest rates, output growth, and real estate prices, but the causation cannot be determined. ${ }^{5}$ We can also see that output growth has both direct and indirect effects on the real

\footnotetext{
${ }^{5}$ When the prime lending rate is used, real estate appreciation is dependent on real interest rate and output growth. However, when the mortgage rate is used, the causal graphs have undirected edges.
} 
A

Impulse response of RECPI (percentage points) to permanent negative 1 percentage shock to CAGDP

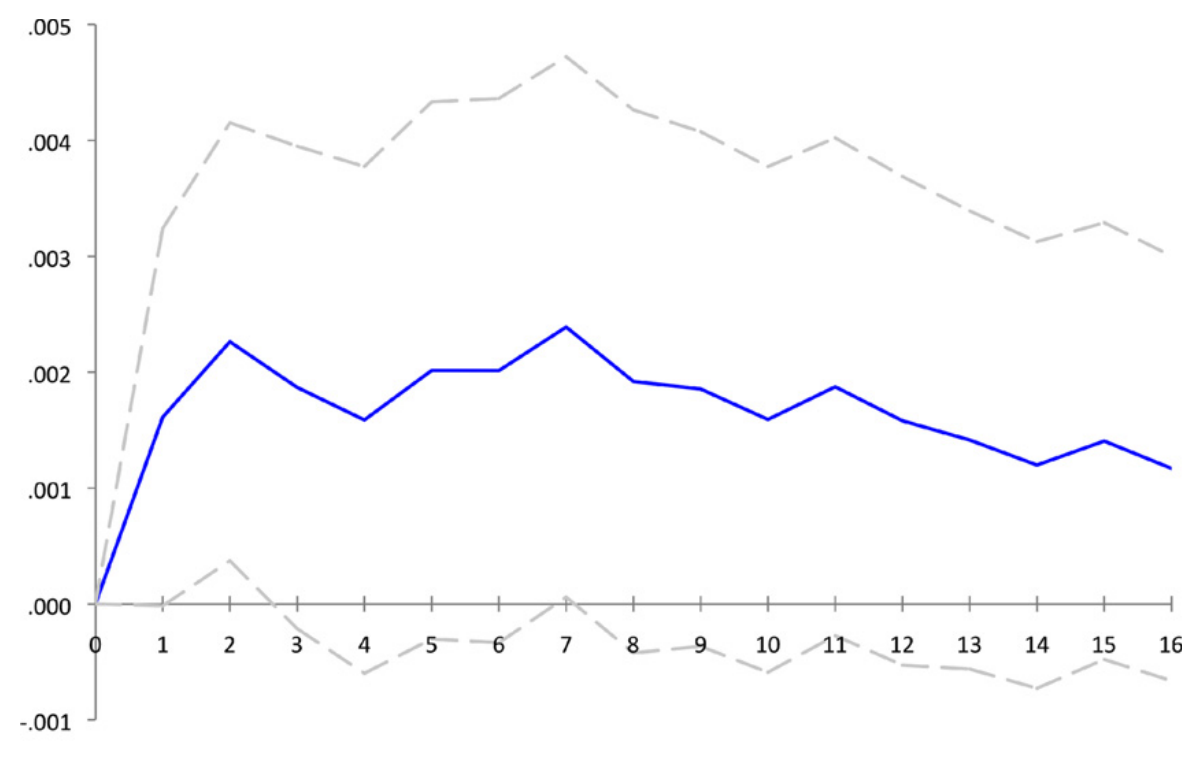

B

Impulse response of INCPI (percentage points) to permanent negative 1 percentage shock to CAGDP

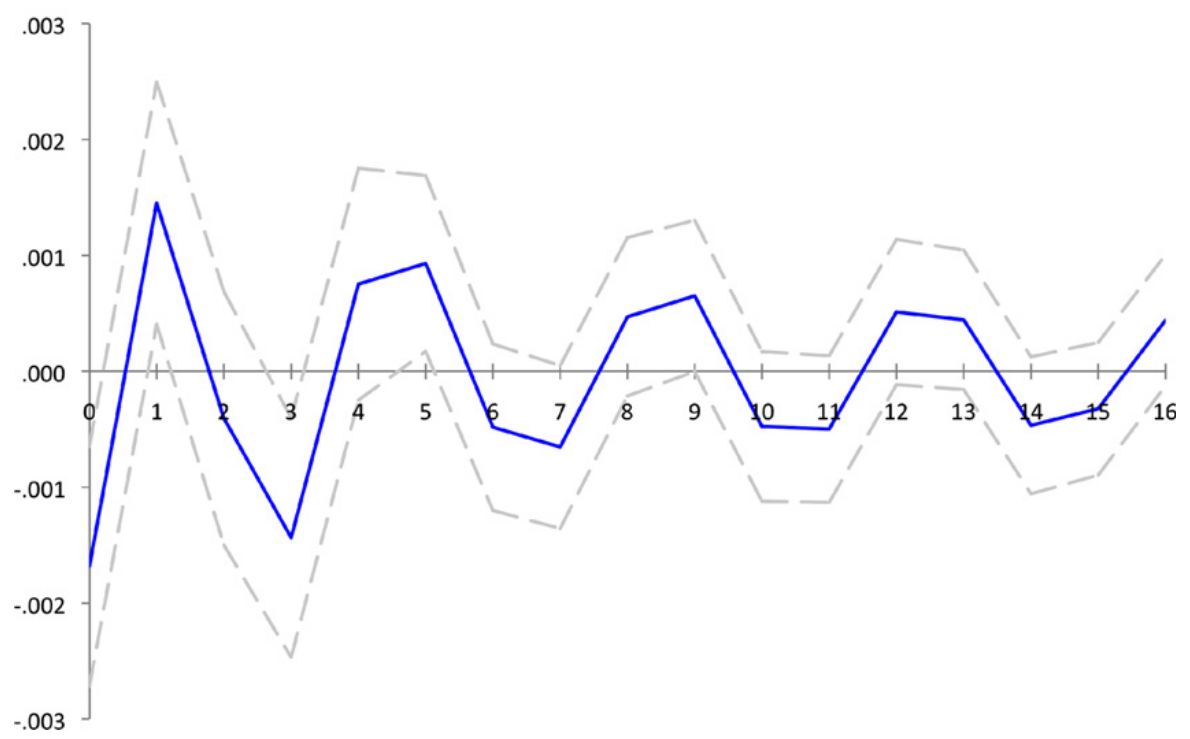

Fig. 3. Impulse response from the structural VAR: United States - western region, from a system using fixed-rate mortgage rate. This figure plots quarterly structural impulse responses of the five-variable (CAGDP, RECPI, INCPI, EQCPI, GDPGR) system based on the causal orders from TETRAD‘s PC search algorithm (with 90 percent interval).

estate appreciations. ${ }^{6}$ In the sectoral data, there is some evidence of linkages from the current account to equity prices. Real estate prices do appear to drive the current account in the sectoral data, but these results are not robust to adjustments for stationarity and should be discounted.

For the United States, the most common causal linkage is from the current account to interest rates, which is evident at the aggregate level (Panel 1B) as well as at regional and city levels (Panels 1E and 1G, using the fixed and flexible mortgage rates). At the regional level, there also appears to be a significant link between real estate prices and mortgage rates (both fixed-rate and adjustable-rate), perhaps reflecting a "demand-pull" effect on mortgage markets from autonomous increases in real estate activity.

The signs of correlations among variables calculated for significant causal links are consistent with our a priori expectations. In England, current account deficits are positively correlated with real estate prices. In the United States, current

\footnotetext{
6 This is consistent with the finding in Case et al. (2000) that a substantial amount of correlation across world real estate markets can be attributed to the effects of changes in national incomes.
} 


\section{A}

Impulse response of RECPI (percentage points) to permanent negative 1 percentage shock to $C A G D P$

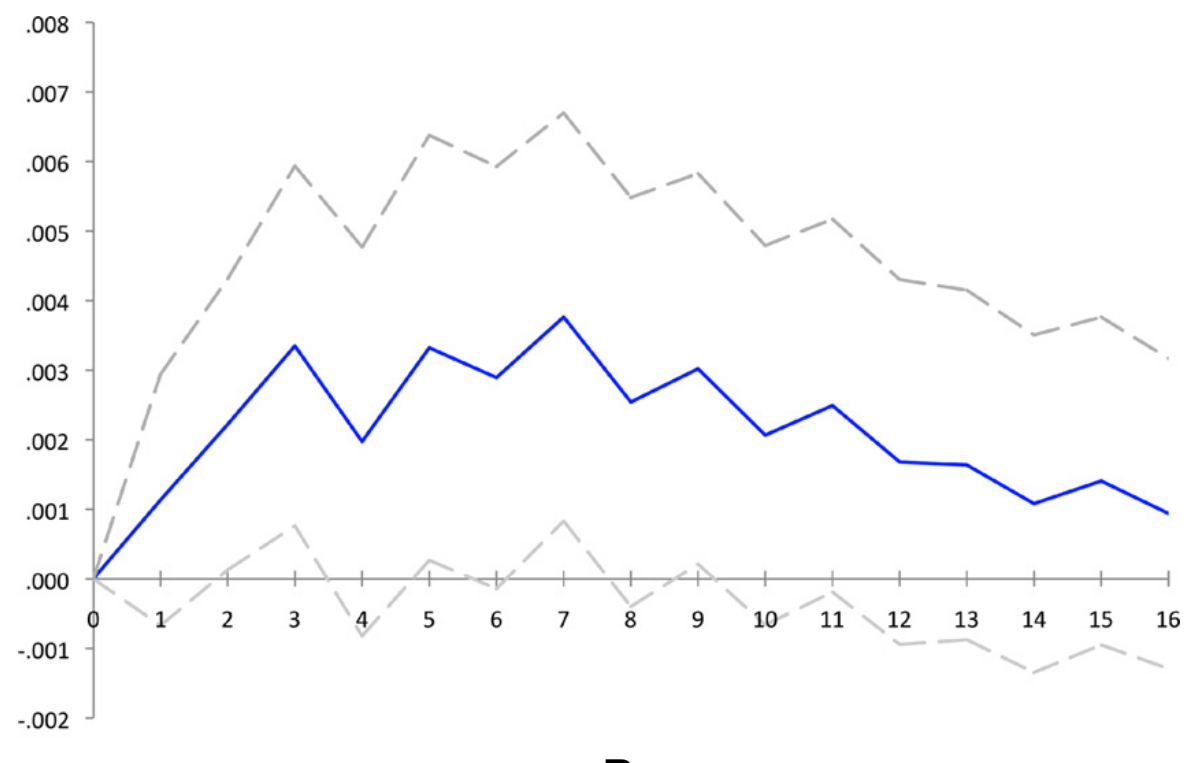

B

Impulse response of $I N C P I$ (percentage points) to permanent negative 1 percentage shock to CAGDP

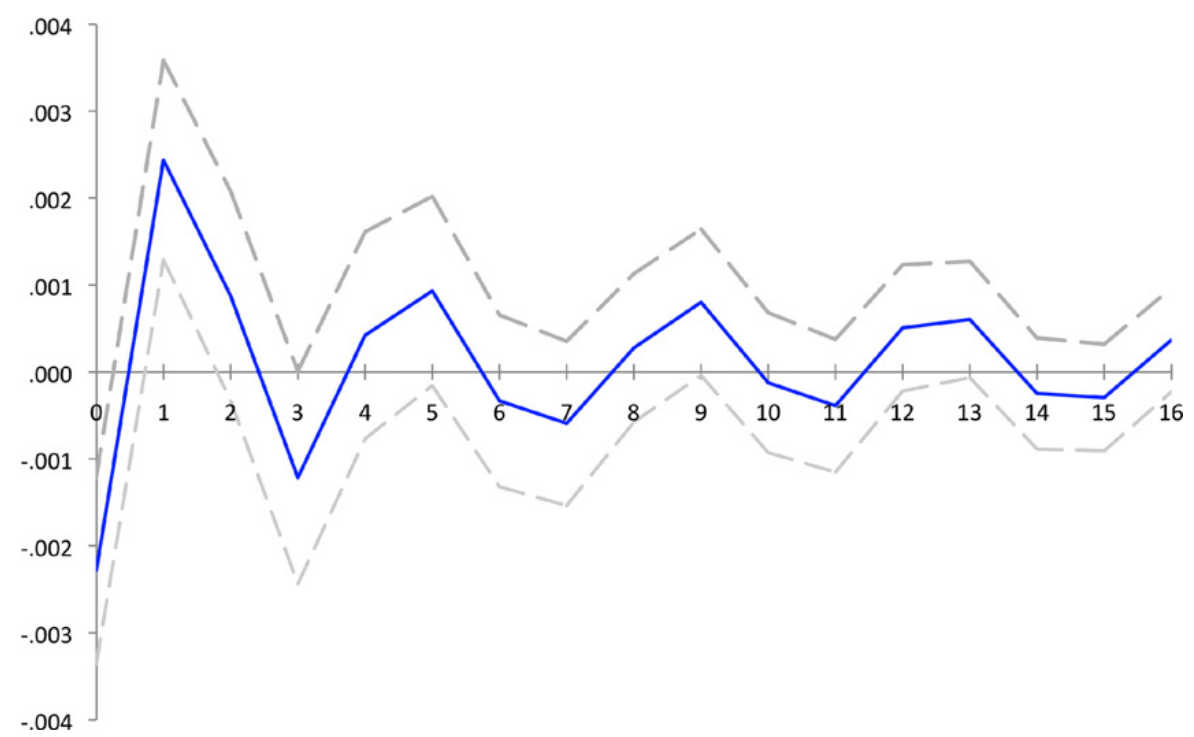

Fig. 4. Impulse response from the structural VAR: United States - western region, from a system using adjustable-rate mortgage interest rates. This figure plots quarterly structural impulse responses of the five-variable (CAGDP, RECPI, INCPI, EQCPI, GDPGR) system based on the causal orders from TETRAD‘s PC search algorithm (with 90 percent interval).

account surpluses are positively correlated with interest rates. Consistent with a demand-pull interpretation, real estate prices are positively correlated with interest rates. ${ }^{7}$ It is important to note that the graph theoretic methods do not rely on the sign of correlations, just their presence. Thus, the fact that we find that the correlations are consistent with our theoretical expectations provides independent validity for our methods.

\subsection{Current account and real estate market}

Once we identify the causal orderings, we can use this information to uncover structural information and, in particular, the effects of structural shocks to the variables. To illustrate the role of current accounts in the real estate markets, we

\footnotetext{
7 Another possibility is the central bank being responsive to real estate markets. Empirical evidence from the industrial countries suggests that monetary policy (short-term interest rates) tend to be transmitted more through the price of homes than through residential investment [WEO, 2008]. However, in a careful reading of official minutes, Ahearne et al. (2005) find little evidence that central banks in industrial countries reacted to rising house prices beyond taking into account their implications for inflation and output growth.
} 
A

Impulse response of RECPI (percentage points) to permanent negative 1 percentage shock to $C A G D P$

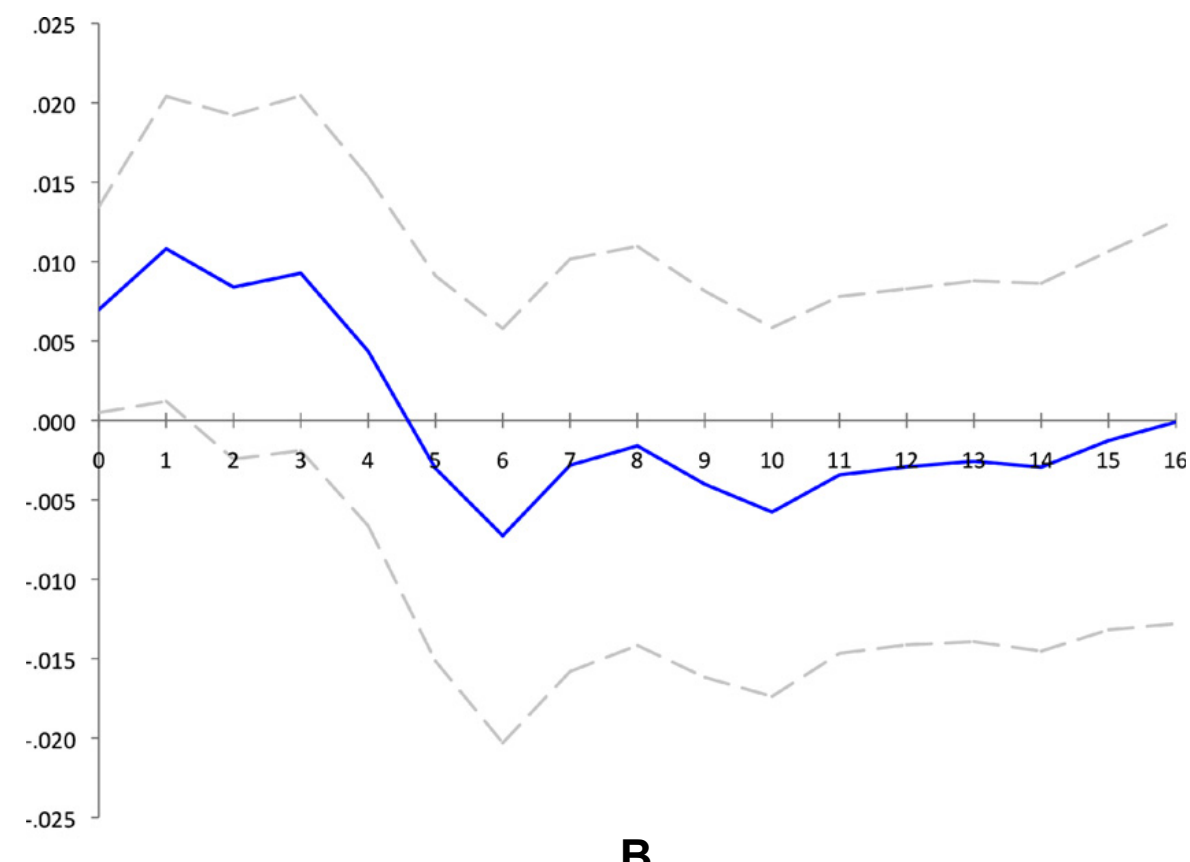

Impulse response of INCPI (percentage points) to permanent negative 1 percentage shock to CAGDP

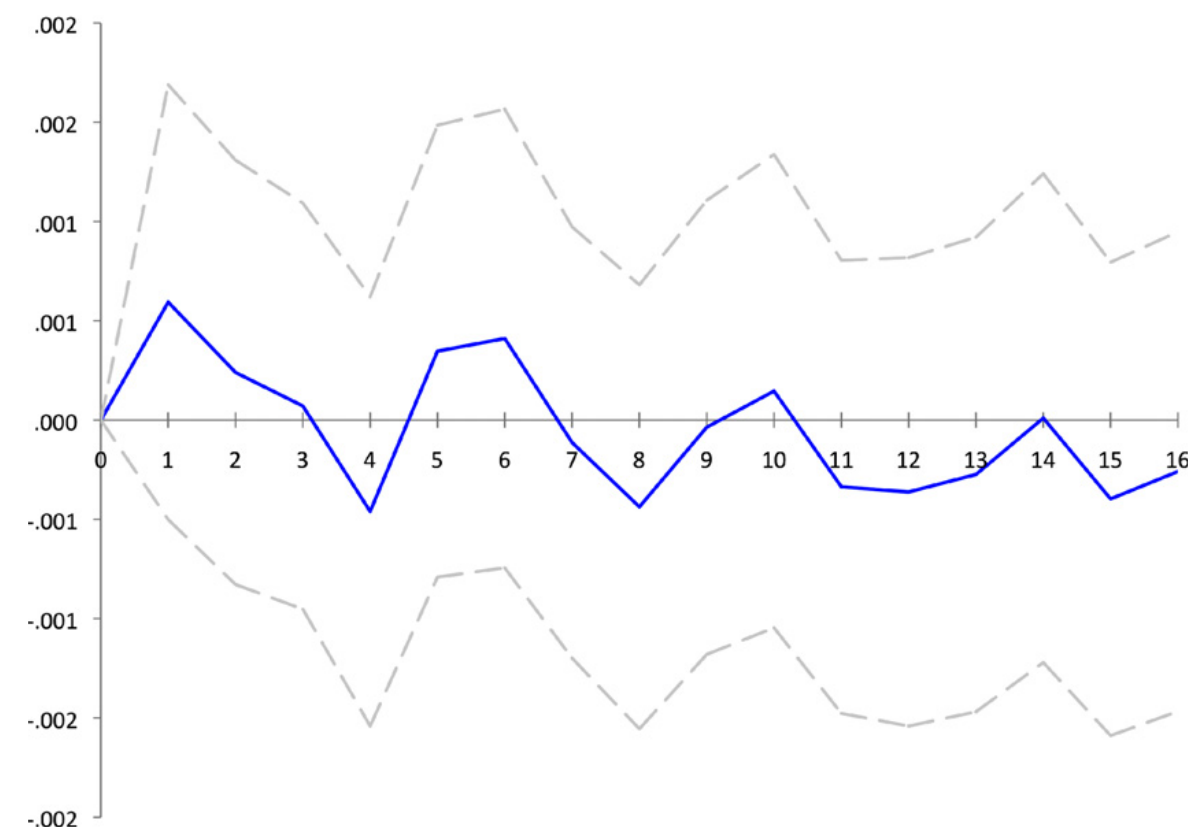

Fig. 5. Impulse response from the structural VAR: England - national market. This figure plots quarterly structural impulse responses of the three-variable (CAGDP, RECPI, INCPI, EQCPI, GDPGR) system based on the causal orders from TETRAD‘s PC search algorithm (with 90 percent interval).

estimate structural VARs for the US-western region and England-national market. We chose these two regions because the causality information was the most complete (having the most identified edges) and provided the most guidance to developing a structural model. Essentially, these results are an upper bound for the possible effects of the current account on real estate prices. Fig. 2 provides causal graphs for these two markets, together with correlations between the variables. For the US - western region in a system using fixed-rate mortgage interest rate, four unidirectional edges point from CAGDP, RECPI, EQCPI, GDPGR to INCPI; appreciations in real estate and equity markets are causally connected, but the direction of causation is unresolved. In the structural model for the US, since the dynamics in real estate markets are slower than that in the equity markets we have equity prices causing real estate appreciation, a choice that we made for illustrative purposes. For England - national market, two unidirectional edges point from CAGDP to RECPI and EQCPI to GDPGR. The contemporaneous effects of CAGDP in both cases have their expected sign. The CAGDP deficits lead to falling mortgage 
interest rates in the USA, while the deficits cause real estate appreciation in England. As we emphasized, this is independent support for our model.

Based on these causal chains obtained from TETRAD's PC algorithm, we can develop the structural models by populating the $A_{0}$ matrices, with non-zero, off-diagonal entries corresponding to the appropriate casual chains:

$$
\begin{aligned}
& Y_{t}^{U S A-W}=[-C A G D P, \text { EQCPI, RECPI, GDPGR, INCPI }]^{\prime} ; A_{0}^{U S A-W}=\left(\begin{array}{cccccc}
1 & 0 & 0 & 0 & 0 \\
0 & 1 & 0 & 0 & 0 \\
0 & a_{32} & 1 & 0 & 0 \\
0 & 0 & 0 & 1 & 0 \\
a_{51} & a_{52} & a_{53} & a_{54} & 1
\end{array}\right) \\
& Y_{t}^{\text {England-National }}=[-C A G D P, \text { EQCPI, RECPI, GDPGR, INCPI }]^{\prime} ; A_{0}^{\text {England-National }}=\left(\begin{array}{ccccc}
1 & 0 & 0 & 0 & 0 \\
0 & 1 & 0 & 0 & 0 \\
a_{31} & 0 & 1 & 0 & 0 \\
0 & a_{42} & 0 & 1 & 0 \\
0 & 0 & 0 & 0 & 1
\end{array}\right)
\end{aligned}
$$

We estimate the SVAR using maximum likelihood with the variables all stationary. For the US-western region, using the fixed-rate mortgage rates, $\hat{a}_{51}=.39($ s.e. $=.14), \hat{a}_{52}=.02($ s.e. $=.009), \hat{a}_{53}=-.13(s . e .=.05), \hat{a}_{54}=.03(s . e .=.01), \hat{a}_{32}=$ $-.029($ s.e. $=.016)$, and Log Likelihood $(\mathrm{LR})$ test of over-identifying restrictions cannot reject the null hypothesis $\left[\chi^{2}(5)=3.91\right.$, Prob. $\left.>\chi^{2}=0.562\right]$. For England-national market, using the variable-rate mortgage rates, $\hat{a}_{31}=-.92($ s.e. $=.51), \hat{a}_{42}=-.16($ s.e. $=.05)$, and LR test of overidentifying restrictions cannot reject the null hypothesis $\left[\chi^{2}(2)=7.391\right.$, Prob. $\left.>\chi^{2}=0.495\right]$. Thus, for both the US-western region and England-national market, the estimated effects are as expected (the off-diagonal elements of the $A_{0}$ matrix contain the negative of the actual contemporaneous effects) and the restrictions imposed from the causal orders are valid.

We then configure SVAR for a system using fixed-rate and for a system using adjustable-rate mortgage interest rate, based on the causal order of the US-western region in Table 1. The structural impulse responses in Fig. 3 Panel 3A shows for the USwestern region the positive effect of capital account surpluses/GDP, - CAGDP, on the real estate appreciation that is statistically significant in the second and seventh quarter. Panel 3B shows that in response to a one percentage shock to the capital account surpluses the decline in real mortgage interest rates, INCPI, is large and statistically significant on impact and the third quarter (though the direction of lagged effects are uncertain as can be seen from the first and fifth quarter, the cumulative response seems to be negative). Notably, using adjustable-rate interest rate shown in Fig. 4A we obtained an impulse response of real estate price to current account deficit over 1-9 quarter horizon that is more persistent than using the fixedrate mortgage rate. This is supportive to the notion that the flexible mortgage rate is one of the factors that deepens the recent recession in the US.

Fig. 5 depicts for England-national market in Panel 5A, the effect of - CAGDP on the real estate appreciation, RECPI, is statistically significant up to the second quarter, then becomes indistinguishable from zero. Thus, capital account surpluses do have an effect on real estate prices in England, but it is short-lived and not persistent. Panel 5B shows that higher current account deficit has no short-run impact on mortgage interest rates. We obtain similar results using the fixed-rate (10-year, 75\% loan-to-value) mortgage rates. In addition, as we estimated SVAR for regional-level data, we find in the England - southeast subsample that higher current account deficit also has a negative impact on the mortgage rates at the fourth quarter after the shock, suggesting its indirect effect operates with about a year lag. The reaction functions of monetary authorities may be influencing these longer run results, particularly for financial markets.

\section{Conclusion}

Untangling causal relations in macro models is very difficult. However, to understand the effects of shocks and the genesis of crisis, it is important to attempt to make causal inferences and uncover structural shocks. The graph theoretic methods employed in this paper can be a useful tool to clarify complex relations, such as those between the current account and real estate prices.

Using a variety of high-quality real estate indices and macro variables, with careful attention to the stationarity of our time series, we find little evidence for strong effects from capital account surpluses directly to real estate. As might be expected from their different institutional structures (as illustrated in our opening quote), there do appear to be differences between the United States and England. In the United States, capital account surpluses do drive down mortgage interest rates temporarily and can have an indirect effect on real estate prices. In England, there is a direct connection, but it is transitory and not permanent. The results from structural VAR serve as the best possible case for current account - real estate price channel.

Our results suggest that drawing analogies between the Asian financial crisis with its own real estate and real exchange rate appreciation and the most recent global crisis may be misplaced. Not only did the Asian countries have less developed 
financial markets but they also typically had fixed exchange rates, in contrast to the US and England. Moreover, our work also suggests that simplistic idea of a "savings glut" driving real estate booms is also misplaced. To the extent that current account surpluses affected real estate, they were mediated through financial markets. In principle, policy makers would have other mechanisms to control financial markets to offset any current account effects.

\section{Appendix A}

\section{A.1. Sources}

\begin{tabular}{|c|c|c|}
\hline Variables & & Sources \\
\hline $\begin{array}{l}\text { Real estate } \\
\text { prices }\end{array}$ & $\begin{array}{l}\text { Regional } \\
\text { City } \\
\text { Sector }\end{array}$ & $\begin{array}{l}\text { United States: National Council of Real Estate Investment Fiduciaries (NCREIF) } \\
\text { England: Nationwide Building Society } \\
\text { Spain: Ministerio de Vivienda } \\
\text { Ireland: Department of the Environment and Local Government } \\
\text { United States: NCREIF } \\
\text { England: Department for Communities and Local Government (DCLG) } \\
\text { United States: Case-Shiller S\&P } \\
\text { England: Investment Property Databank (IPD) } \\
\text { Ireland: IPD }\end{array}$ \\
\hline $\begin{array}{l}\text { Current } \\
\text { account }\end{array}$ & & Eurostat \\
\hline GDP & & Eurostat \\
\hline Interest rates & $\begin{array}{l}\text { Prime } \\
\text { lending }\end{array}$ & $\begin{array}{l}\text { United States: Freddie Mac } 30 \text {-year fixed-rate and adjustable-rate (ARM) } \\
\text { England: Standard variable rates from the Banks \& Buildings Society (Bank of England } \\
\text { database) } \\
\text { Ireland: Central Bank of Ireland (house purchase loan average interest rate) } \\
\text { United States: IMF } \\
\text { England: IMF } \\
\text { Ireland: IMF } \\
\text { Spain: IMF }\end{array}$ \\
\hline Equity prices & & $\begin{array}{l}\text { United States: NYSE Composite } \\
\text { England: FTSE All share } \\
\text { Spain: Madrid SE General } \\
\text { Ireland: ISEQ }\end{array}$ \\
\hline CPI & & Datastream \\
\hline
\end{tabular}

\section{A.2. Sample periods and stationarity}

\begin{tabular}{|c|c|c|c|c|c|}
\hline \multirow[t]{2}{*}{ Country } & \multirow[t]{2}{*}{ Variable } & \multicolumn{2}{|c|}{ Sample period } & \multicolumn{2}{|c|}{ Null: unit root } \\
\hline & & & & Level & Difference \\
\hline \multicolumn{6}{|c|}{ Current account/GDP } \\
\hline USA & & $2008 \mathrm{q} 4$ & 1980q2 & .4381 & .0000 \\
\hline England & & 2009q1 & 1984q1 & .0000 & \\
\hline Ireland & & 2009q1 & 1997q2 & .0294 & .0000 \\
\hline Spain & & 2009q1 & $1993 q 2$ & .8412 & .0000 \\
\hline \multicolumn{6}{|c|}{ Equity market appreciation (deflated by CPI) } \\
\hline USA & & 2009q1 & $1966 q 2$ & .0000 & \\
\hline England & & $2009 q 1$ & $1962 q 4$ & .0000 & \\
\hline Ireland & & 2009q1 & $1983 q 3$ & .0000 & \\
\hline Spain & & 2009q1 & $1974 q 3$ & .0000 & \\
\hline
\end{tabular}


Appendix A.2 (continued)

\begin{tabular}{|c|c|c|c|c|c|}
\hline \multirow[t]{2}{*}{ Country } & \multirow[t]{2}{*}{ Variable } & \multicolumn{2}{|c|}{ Sample period } & \multicolumn{2}{|c|}{ Null: unit root } \\
\hline & & & & Level & Difference \\
\hline \multicolumn{6}{|c|}{ GDP growth } \\
\hline USA & & $2009 q 1$ & $1971 q 2$ & .0000 & \\
\hline England & & 2009q1 & $1971 q 2$ & .0000 & \\
\hline Ireland & & $2009 q 1$ & $1997 q 2$ & .0000 & \\
\hline Spain & & $2009 q 1$ & $1980 q 2$ & .0000 & \\
\hline \multicolumn{6}{|c|}{ Mortgage interest rate (deflated by CPI) } \\
\hline \multirow[t]{2}{*}{ USA } & Fixed-rate & 2009q1 & $1971 q 4$ & .4855 & .0000 \\
\hline & Adjustable-rate (ARM) & $2009 q 1$ & $1986 q 4$ & .0566 & .0000 \\
\hline England & Standard variable rate (SVR) & 2009q1 & $1995 q 2$ & .0119 & .0000 \\
\hline Ireland & Fixed-rate & 2009q1 & $1975 q 2$ & .5010 & .0000 \\
\hline \multicolumn{6}{|c|}{ Prime lending interest rate (deflated by CPI) } \\
\hline USA & & 2009q1 & $1957 q 3$ & .1308 & .0000 \\
\hline England & & $2009 q 1$ & $1966 q 4$ & .2571 & .0000 \\
\hline Ireland & & $2009 q 1$ & 1992q2 & .0804 & .0000 \\
\hline Spain & & 2009q1 & $1982 \mathrm{q} 2$ & .5145 & .0000 \\
\hline \multirow[t]{17}{*}{ USA } & National & 2009q1 & $1978 q 2$ & .0202 & .0000 \\
\hline & West & $2009 q 1$ & $1978 q 1$ & .0002 & \\
\hline & South & $2009 q 1$ & $1978 q 1$ & .0001 & \\
\hline & East & 2009q1 & 1978q1 & .0002 & \\
\hline & Mid-West & $2009 q 1$ & $1978 q 1$ & .0000 & \\
\hline & Case-Shiller Aggregate & 2009q1 & $1987 q 3$ & .8724 & .0000 \\
\hline & Case-Shiller 10 cities & $2009 q 1$ & $1987 q 3$ & .8269 & .0000 \\
\hline & Denver & $2009 q 1$ & $1987 q 2$ & .0034 & \\
\hline & San Francisco & $2009 q 1$ & $1987 q 3$ & .4454 & .0000 \\
\hline & Washington D.C. & $2009 q 1$ & $1987 q 3$ & .6567 & .0000 \\
\hline & New York & $2009 q 1$ & $1987 q 3$ & .7682 & .0000 \\
\hline & Boston & $2009 q 1$ & $1987 q 3$ & .0152 & .0000 \\
\hline & Las Vegas & $2009 q 1$ & $1987 q 3$ & .3593 & .0000 \\
\hline & Michigan & 2009q1 & $1987 q 3$ & .5840 & .0000 \\
\hline & San Diego & 2009q1 & $1987 q 3$ & .3375 & .0000 \\
\hline & Chicago & $2009 q 1$ & $1987 q 3$ & .9845 & .0000 \\
\hline & Los Angeles & 2009q1 & $1987 q 3$ & .3861 & .0000 \\
\hline \multirow[t]{12}{*}{ England } & National & $2009 q 1$ & $1957 q 2$ & .0000 & \\
\hline & West Midlands & $2009 q 1$ & $1968 \mathrm{q} 3$ & .0000 & \\
\hline & London & 2009q1 & $1968 q 3$ & .0000 & \\
\hline & East Midlands & 2009q1 & $1968 q 3$ & .0000 & \\
\hline & Yorkshire and Humberside & $2009 q 1$ & $1968 q 3$ & .0000 & \\
\hline & East & 2009q1 & $1992 q 3$ & .0000 & \\
\hline & South East & $2009 q 1$ & $1992 q 3$ & .0000 & \\
\hline & North East & $2009 q 1$ & $1992 q 3$ & .0000 & \\
\hline & IPD Total & $2009 q 1$ & $1987 q 2$ & .0208 & .0000 \\
\hline & IPD Office & $2009 q 1$ & $1987 q 2$ & .0424 & .0000 \\
\hline & IPO Retail & 2009q1 & 1987q2 & .0737 & .0000 \\
\hline & IPD Industrial & $2009 q 1$ & $1987 q 2$ & .0345 & .0000 \\
\hline \multirow[t]{5}{*}{ Ireland } & National & 2009q1 & 1991q2 & .0031 & \\
\hline & IPD Total & $2009 q 1$ & $1995 q 2$ & .4330 & .0000 \\
\hline & IPD Office & 2009q1 & $1995 q 2$ & .5110 & .0000 \\
\hline & IPD Retail & $2009 q 1$ & $1995 q 2$ & .2382 & .0000 \\
\hline & IPD Industrial & 2009q1 & $1995 q 2$ & .3677 & .0000 \\
\hline Spain & National & $2009 q 1$ & $1995 q 2$ & .0008 & \\
\hline
\end{tabular}

This table provides the sample period for all the variables and corresponding $p$-values of the Phillips-Perron test under the null of unit root. 


\section{References}

Ahearne, A.G., Ammer, J., Doyle, B.M., Kole, L.S., Martin, R.F., 2005. Monetary Policy and House Prices: A Cross-country Study. International Finance Discussion Papers 841. Board of Governors of the Federal Reserve System.

Aizenman, J., Jinjarak, Y., 2009. Current account patterns and national real estate markets. Journal of Urban Economics 66 (2), $75-89$.

Bosworth, B., Flaaen, A., 2009. Financial crises american style. Asian Economic Papers 8 (3), 146-170.

Campbell, J.Y., Cocco, J.F., 2007. How do house prices affect consumption? Evidence from micro data. Journal of Monetary Economics 54 (3), 591-621.

Case, B., Goetzmann, W.N., Rouwenhorst, K.G. 2000. Global Real Estate Markets - Cycles and Fundamentals. NBER Working Paper No. 7566.

Case, K.E., Shiller, R.J., 2005. Comparing wealth effects: the stock market versus the housing market. Advances in Macroeconomics 5 (1).

Demiralp, S., Hoover, K.D., 2003. Searching for the causal structure of a vector autoregression. Oxford Bulletin of Economics and Statistics 65 (Suppl.), 745767.

Demiralp, S., Hoover, K.D., Perez, S.J., 2009. Empirical identification of the vector autoregression: the causes and effects of US M2. In: Castle, Jennifer L., Shephard, Neil (Eds.), The Methodology and Practice of Econometrics. Oxford University Press, pp. 37-58.

Engelhardt, G.V., 1996. House prices and home owner saving behavior. Regional Science and Urban Economics 26 (3-4), 313-336.

Glaeser, E.L., Gyourko, J. 2007. Arbitrage in Housing Markets. NBER Working Paper No. 13704.

Granger, C.W.J., Swanson, N.R., 1997. Impulse response functions based on a causal approach to residual orthogonalization in vector autoregressions. Journal of the American Statistical Association 92 (437), 357-367.

Hoover, K.D., Demiralp, S., Perez, S.J., 2009. Empirical identification of the vector autoregression: the causes and effects of US M2. In: Castle, J.L., Shephard, N. (Eds.), The Methodology and Practice of Econometrics. Oxford University Press, New York, pp. 37-58.

Hoover, K.D., Sheffrin, S.M., 1992. Causation, spending, and taxes: sand in the sandbox or tax collector for the welfare state? American Economic Review 82 (1), 225-248.

Pearl, J.M., 2009. Causality: models, reasoning, and inference. Cambridge University Press.

Perez, S.J., Siegler, M.V., 2006. Agricultural and monetary shocks before the great depression: a graph-theoretic causal investigation. Journal of Macroeconomics 28 (4), 720-736.

Reinhart, C.M., Rogoff, K.S., 2008. Is the 2007 US sub-prime financial crisis so different? an international historical comparison. American Economic Review 98 (2), 339-344.

Romer, C.D., Romer, D.H., 2010. The macroeconomic effects of tax changes: estimates based on a new measure of fiscal shocks. American Economic Review 100 (3), 763-801.

Sheffrin, S.M., Triest, R.K., 1995. A New Approach to Causality and Economic Growth. Federal Reserve Bank of Boston, Working Paper 95-12.

Spirtes, P., Glymour, C., Scheines, R., 2000. Causation Prediction and Search. MIT Press.

WEO, 2008. The Changing Housing Cycle and the Implications for Monetary Policy. International Monetary Fund.

Yamashita, T., 2007. House price appreciation, liquidity constraints, and second mortgages. Journal of Urban Economics 62 (3), 424-440. 